\title{
PENGARUH PERSISTENSI DIRI TERHADAP PRESTASI BELAJAR MATEMATIKA SISWA DI SMP AL-QALAM
}

\author{
Mohamad Lutfi Nugraha \\ Dosen Program Studi Teknik dan Ilmu Komputer Universitas Indraprasta PGRI \\ Email : muhammadlutfinugraha@yahoo.co.id
}

\begin{abstract}
Abstrak
Tujuan Penelitian adalah untuk mengetahui pengaruh persistensi diri siswa terhadap pretasi belajar matematika siswa pada semester dua tahun pelajaran 2016/2017. Metode yang digunakan dalam penelitian ini adalah metode survey. jumlah Sampel yang diguanakan di dalam penelitian ini diambil secara sederhana (simple random sampling) dengan mengambil sampel 40 siswa. Pada angket persistensi diri siswa rata-rata tes yaitu 75,3, median 76,61, modus 68,83, simpangan baku 8,167, dan koefisien variasi 66,71 sedangkan prestasi belajar siswa rata-rata tes yaitu 69,45, median 73,5, modus 80,04 simpangan baku 12,513, dan koefisien variasi 156,59 . Koefisien regresi untuk penelitian ini adalah $\mathrm{Y}=70,78+0,58 \mathrm{X}$ Koefisien korelasi $=0,9$, koefisien determinasi $81 \%$ dan uji keberartian regresi 231,02. Uji hipotesis menggunakan uji-t diperoleh $t_{\text {hitung }}=12,9$ pada taraf signifikan $\alpha=0,05$ dan derajat kebebasan $(\mathrm{dk})=38$ didapat $\mathrm{t}_{\text {tabel }}=1,6905$ Karena $\mathrm{t}_{\text {hitung }}>\mathrm{t}_{\text {tabel }}$ atau 12,9 $>1,6905 \mathrm{Maka} \mathrm{H}_{0}$ ditolak dan $\mathrm{H}_{1}$ diterima. Dengan demikian disimpulkan bahwa ada pengaruh positif antara persistensi diri siswa terhadap prestasi belajar matematika siswa.
\end{abstract}

Kata Kunci : Persistensi diri. Prestasi Belajar Matematika

\section{PENDAHULUAN}

Matematika sampai saat ini masih menjadi sesuatu yang ditakuti oleh sebagian anak-anak, oleh karena itu semua ini menjadi suatu permasalahan pendidikan yang terdapat dalam bidang pendidikan. Kesimpulannya bagaimana mengubah kepribadian siswa yang merasa takut dan tidak senang terhadap matematika, ini semua harus diperhatikan dengan seksama oleh setiap guru.

Keberhasilan dan kegagalan siswa dalam belajar tersebut dipengaruhi oleh beberapa faktor. Untuk menyatakan bahwa suatu proses belajar dapat dikatkan berhasil, setiap guru memiliki pandangan masing-masing sesuai dengan filsafatnya. Namun untuk menyamakan persepsi sebaiknya kita berpedoman pada kurikulum yang berlaku pada saat ini yang telah disempurnakan, antara lain yang telah dikemukakan oleh Bahri dan Zain (2006 : 119) bahwa suatu proses belajar tentang suatu bahan pegajaran dinyatakan berhasil apabila tujuan instruksional khusus (TIK)-nya dapat tercapai.

Banyak fakor-faktor yang mempengaruhi prestasi matematika siswa baik berasal dari dalam diri siswa ataupun diluar diri siswa. Salah satu faktor yang mempengaruhinya yaitu kebiasaan belajar dari dalam diri siswa tersebut. Kebiasaan belajar itu sendiri merupakan cerminan dari cara belajar siswa tersebut didalam kehidupan sehari-hari baik disekolah maupun dirumah. 
Oleh karena itu, dapat disimpulkan bahwa kepribadiaan dari setiap siswa yang mempunyai perisitensi diri yang baik dapat mempengaruhi terhadap prestasi matematika serta dapat mengatasai kegagalan dalam belajar matematika. Kegagalan dalam pembelajaran matematika itu tidak terlepas dari kemalesan siswa dikarenakan dari awalnya siswa tidak memiliki ketetapan diri serta konsistensi diri. Permasalahan ini menjadi acuan bagi berbagai pihak yang peduli terhadap pendidikan khususnya matematika, tertama bagi seorang guru yang secara langsung melaksankan proses belajar bersama siswa. Oleh sebab itu, siswa harus mempunyai persistensi diri atau ketetapan diri dalam proses belajar matematika, alhasil matematika bukan menjadi momok bagi para siswa.

Persistensi diri dalam setiap siswa perlu ditingkatkan untuk menunjang proses berhasilnya pembelajaran dalam matematika. Disinilah peran guru yang sangat potensial untuk meningkatkan persistensi diri atau ketetapan dari siswa dalam belajar matematika itu sendiri disamping faktor eksternal juga diperlukan. Tentunya pasti akan ada perbedaaan antara siswa yang mempunyai persistensi diri dan siswa yang tidak mempunyai persistensi diri dalam keberhasilan belajar, khususnya matematika.

Dari penjelasan di atas dapat disimpulkan keberhasilan setiap siswa salah satunya dapat dilihat dari persistensi diri siswa itu sendiri. Oleh sebab itu penulis, termotivasi untuk membuat sebuah penelitian mengenai sejauh mana "Pengaruh Persistensi Diri Terhadap Prestasi Belajar Operasi Hitung Bentuk Aljabar Siswa pada kelas VIII di Sekolah Menengah Pertama Al-Qalam Jakarta Timur”.

\section{TINJAUAN PUSTAKA}

\section{Prestasi Belajar Matematika}

Menurut Dimyati dan Mudjiono (2006:22), prestasi belajar siswa berarti "tercapainya tujuan belajar siswa". Dengan demikian tercapainya tujuan intruksional, dan sekaligus tujuan belajar "perantara" bagi siswa. Prestasi belajar matematika siswa berarti tercapainya tujuan belajar matematika siswa. Prestasibelajar siswa merupakan prasyarat bagi program belajar selanjutnya.

Disamping itu Sudjana (2004 : 3) menyampaikan bahwa prestasi belajar adalah perubahan tingkah laku yang mecakup kognitif, afektif, dan psikomotorik.

Dari keterangan di atas jelaslah bahwa seseorang yang sudah belajar tidak sama keadaannya dengan saat kita yang belum belajar. Perbedaannya antara 
sebelum dan sesudah mendapatkan pengalaman belajar, itulah yang dimaksud dengan prestasi belajar.

Berdasarkan kajian teori diatas, dapat disimpulkan prestasi belajar matematika adalah perubahan-perubahan tingkah laku siswa sebagai indikator tingkat ketercapaian tujuan belajar matematikadalam penguasaan struktur kognitif berupa fakta-fakta, dan konsep-konsep setelah mendapatkan pengalaman belajar di bidang matematika.

\section{Operasi Hitung pada Bentuk Aljabar}

Sebelum mempelajari penjumlahan dan pengurangan pada bentuk aljabar, kita harus mengetahui suku-suku dari bentuk aljabar tersebut. Yaitu suku-suku sejenis dan suku-suku yang tidak sejenis.

Suku sejenis adalah suku yang memiliki variable dan pangkat dari masingmasing variabel yang sama. Contohnya seperti berikut: $3 x^{2}-2 x+3 y+2 x^{2}+5$. Suku-suku $3 x^{2}$ dan $2 x^{2}$ itu disebut suku-suku sejenis. Sedangkan $-2 x$ dan $3 y$ merupakan suku-suku yang tidak sejenis.

Pemahaman mengenai suku-suku sejenis dan suku-suku tidak sejenis sangat bermanfaat dalam menyelesaikan operasi penjumlahan dan pengurangan dari bentuk aljabar. Operasi penjumlahan dan pengurangan pada bentuk aljabar dapat diselesaikan dengan memanfaatkan sifat komutatif, asosiatif dan distributive. Dengan memperhatikan suku-suku yang sejenis.

Contoh :

1. Tentukan hasil penjumlahan $3 x^{2}-2 x+5$ dengan $x^{2}+4 x-3$.

2. Tentukan hasil pengurangan $4 y^{2}-3 y+2$ dari $2\left(2 y^{2}-3\right)$ Jawab :

1. $\left(3 x^{2}-2 x+5\right)+\left(x^{2}+4 x-3\right) 2 \cdot 2\left(2 y^{2}-3\right)-\left(4 y^{2}-3 y+2\right)$

$$
\begin{aligned}
& =3 \mathrm{x}^{2}-2 \mathrm{x}+5+\mathrm{x}^{2}+4 \mathrm{x}-3 \quad=4 \mathrm{y}^{2}-6-4 \mathrm{y}^{2}+3 \mathrm{y}+2 \\
& =3 \mathrm{x}^{2}+\mathrm{x}^{2}-2 \mathrm{x}+4 \mathrm{x}+5-3 \quad=4 \mathrm{y}^{2}-4 \mathrm{y}^{2}+3 \mathrm{y}-6+2 \\
& =4 \mathrm{x}^{2}+2 \mathrm{x}+2 \quad=3 \mathrm{y}-4
\end{aligned}
$$

\section{Persistensi Diri}

Seligman dan Peterson (2004) mendefinisikan persistensi kelanjutan dari tindakan sukarela yang dilakukan untuk mencapai suatu tujuan meskipun ada hambatan, kesulitan atau keputusasaan. 
Persistensi identik dengan konsistensi, kedua-duanya saling berhubungan satu sama lain. Persistensi merupakan suatu perilaku yang berhubungan dengan kepribadian. Untuk mencapai tujuan yang diharapkan memerlukan persistensi dari sejak dini. apabila sejak dini diterapkan persistensi kepribadiaan dengan ranah yang positif maka hasilnya akan terus bersifat positif.

Berdasarkan pernytaan di atas dapat disimpulkan bahwa persistensi diri adalah suatu prilaku atau aktifitas yang dikerjakan secara keihklasan atau sukarela untuk mencapai tujuan yang diinginkan walaupun mendapatkan hambatan, kesulitan atau keputusasaan.

\section{METODE}

\section{Jenis Penelitian}

Jenis penelitian yang digunakan di dalam penelitian ini adalah kuantitatif dengan metode survey. Analaisis data yang digunakan adalah analisis korelasi, regresi sederhana untuk mengetahui pengaruh persistensi diri terhadap prestasi belajar operasi hitung pada bentuk aljabar.

\section{Desain Penelitian}

Adapun desain dalam penelitian ini disusun sebagai berikut :

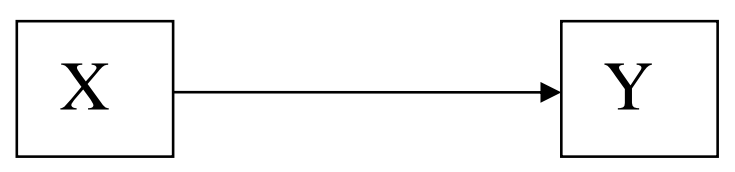

\section{Gambar.1 Desain}

$\mathrm{X} \quad$ : Peristensi diri siswa

Y : Prestasi belajar operasi hitung pada bentuk aljabar siswa

\section{HASIL DAN PEMBAHASAN}

\section{Hasil Penelitian}

\section{Uji Normalitas Persistensi Diri}

Hasil pengujian dengan menggunakan SPSS 20 diperoleh :

Tabel 1. Uji Normalitas Persistensi Diri

\begin{tabular}{|c|c|c|}
\hline & & Persistensi Diri \\
\hline $\mathrm{N}$ & & 40 \\
\hline Normal Parameters $\mathrm{a}^{\mathrm{a}}$ & Mean & 69,4500 \\
\hline
\end{tabular}




\begin{tabular}{|llr|} 
& Std. \\
& Deviation & 12,513 \\
Most Extreme & Absolute & 0,090 \\
Differences & Positive & 0,052 \\
& Negative & $-0,090$ \\
Kolmogorov-Smirnov Z & & 0,0889 \\
Asymp. Sig. (2-tailed) & & 0,140 \\
\hline
\end{tabular}

a. Test distribution is Normal.

b. Calculated from data

\section{Interpretasi}

Dalam menginterpretasikan data hasil uji normalitas kita lihat kolom Persitensi Diri, Terdapat nilai Kosmogorov Smirnov = 0,0889 dengan probabilitas 0,140 (Asymp. Sig. (2-tailed)).

Persyaratan data berdistribusi normal jika probabilitas atau $\mathrm{p}>0,05$ pada uji normalitas dengan Kolmogorov Smirnov. Oleh karena nilai $\mathrm{p}=0,140$, atau $\mathrm{p}>$ 0,05, maka $\mathrm{H}_{0}$ diterima dan $\mathrm{H}_{1}$ ditolak. Artinya data Persitensi Diri berasal dari populasi yang berdistribusi normal.

\section{Uji Normalitas Prestasi Belajar}

Hasil pengujian dengan menggunakan SPSS 20 diperoleh :

Tabel 1. Uji Normalitas Prestasi Belajar

\begin{tabular}{|ll|r|}
\hline & & Prestasi Belajar \\
\hline $\mathrm{N}$ & & 40 \\
Normal Parameters $^{\mathrm{a}}$ & Mean & 69,8000 \\
& Std. & \\
& Deviation & 13,773 \\
Most Extreme & Absolute & 0,090 \\
Differences & Positive & 0,052 \\
& Negative & $-0,090$ \\
Kolmogorov-Smirnov Z & & 0,091 \\
Asymp. Sig. (2-tailed) & & 0,142 \\
\hline
\end{tabular}

c. Test distribution is Normal.

d. Calculated from data 
Interpretasi

Dalam menginterpretasikan data hasil uji normalitas kita lihat kolom Prestasi Belajar, Terdapat nilai Kosmogorov Smirnov = 0,091 dengan probabilitas 0,142 (Asymp. Sig. (2-tailed)).

Persyaratan data berdistribusi normal jika probabilitas atau $\mathrm{p}>0,05$ pada uji normalitas dengan Kolmogorov Smirnov. Oleh karena nilai $\mathrm{p}=0,142$, atau $\mathrm{p}>$ 0,05, maka $\mathrm{H}_{0}$ diterima dan $\mathrm{H}_{1}$ ditolak. Artinya data Prestasi Belajar berasal dari populasi yang berdistribusi normal.

\section{Uji Linieritas Regresi}

Dari perhitungan diperoleh $\sum \mathrm{Y}=2999, \sum \mathrm{X}=2793, \sum \mathrm{XY}=213.715, \sum \mathrm{X}^{2}$ $=202.419, \sum Y^{2}=227.761, n=40$. Untuk mengetahui persamaan regresi dari data persistensi diri dan prestasi belajar operasi hitung pada bentuk aljabar, terlebih dahulu dicari a dan $\mathrm{b}$ dengan menggunakan rumus sebagai berikut:

$$
\begin{aligned}
\mathrm{b} & =\frac{\mathrm{n} \sum \mathrm{xy}-\left(\sum \mathrm{x}\right)\left(\sum \mathrm{y}\right)}{\mathrm{n} \sum \mathrm{x}^{2}-\left(\sum \mathrm{x}\right)^{2}} \\
& =\frac{40 \mathrm{x} 213.715-(2793 \times 2999)}{40 \times 202.419-(2793)^{2}} \\
& =\frac{8548600-8376207}{8096760-7800849}=\frac{172393}{295911}=0,583 \\
\mathrm{a} & =\frac{\sum \mathrm{Y}-\mathrm{b} \sum \mathrm{X}}{\mathrm{n}}=\frac{2999-(0,06 \times 2793)}{40} \\
& =\frac{2999-167,58}{40}=\frac{2831,42}{40}=70,78
\end{aligned}
$$

Dari perhitungan diatas maka diperoleh persamaan regresi linier dari data persistensi diri siswa dan prestasi belajar operasi hitung pada bentuk aljabar sebagai berikut:

$$
\begin{aligned}
\widehat{Y} & =a+b X \\
& =70,78+(0,583) X
\end{aligned}
$$

Dari persamaan regresi tersebut, karena koefisien regresi $\mathrm{b}$ bernilai positif yaitu 0,583 maka dapat disimpulkan bahwa pengaruh variabel $\mathrm{X}$ ( persistensi diri) memberikan pengaruh yang positif terhadap variabel Y ( prestasi belajar operasi hitung pada bentuk aljabar). 


\section{Uji kelinieran regresi}

Dari perhitungan diperoleh $\sum \mathrm{Y}=2999, \sum \mathrm{X}=2793, \sum \mathrm{XY}=213.715, \sum \mathrm{X}^{2}$ $=202.419, \sum \mathrm{Y}^{2}=227.761, \mathrm{n}=40$. Untuk menghitung kelinieran regresi yaitu dengan menggunakan anava yaitu dengan langkah- langkah sebagai berikut:

a. Menentukan jumlah kuadrat regresi a (JKa)

$$
\mathrm{JKa}=\frac{\left(\sum \mathrm{Y}\right)^{2}}{\mathrm{n}}=\frac{(2999)^{2}}{40}=\frac{8994001}{40}=224850,025
$$

b. Menentukan jumlah kuadrat regresi a terhadap b (Jkba)

$\mathrm{JKb} / \mathrm{a}=\mathrm{b}\left\{\sum \mathrm{XY}-\frac{\sum \mathrm{x} \sum \mathrm{y}}{\mathrm{n}}\right\}=0,583\left\{213.715-\frac{2793 \times 2999}{40}\right\}=0,58 \mathrm{x}$

$(213.715-209.405,17=2499,6985$

c. Menentukan jumlah residu (JKr)

$\mathrm{JKr}=\sum \mathrm{Y}^{2}-\mathrm{Jkb} / \mathrm{a}-\mathrm{Jka}$

$=227.761-2499,6985-224850,025=411,2765$

d. Menentukan jumlah kuadrat kekeliruan atau error (JKkk)

$(\mathrm{JKkk})=\sum\left(\sum \mathrm{Y}^{2}-\frac{\left(\sum \mathrm{Y}\right)^{2}}{\mathrm{n}}\right)=805.210$

e. Menentukan kebebasan kekeliruan (dbkk)

$(\mathrm{dbkk})=\mathrm{n}-\mathrm{k}=40-18=22$

f. Menentukan derajat kebebasan ketidakcocokan (dbtc)

$(\mathrm{dbtc})=\mathrm{k}-2=18-2=16$

g. Menentukan jumlah kuadrat ketidakcocokan (JKtc)

$(\mathrm{JKtc})=\mathrm{JKr}-\mathrm{JKkk}=411,2765-805210=-804798,7235$

h. Menentukan rata-rata kuadrat kekeliruan (RKkk)

$(\mathrm{RKkk})=\frac{\mathrm{JKkk}}{\mathrm{dbkk}}=\frac{\mathrm{JKkk}}{\mathrm{n}-\mathrm{k}}=\frac{805210}{22}=36600,45$

i. Menentukan rata-rata kuadrat ketidakcocokan (RKtc)

$(\mathrm{RKtc})=\frac{\mathrm{JKtc}}{\mathrm{dbtc}}=\frac{\mathrm{Jktc}}{\mathrm{K}-2}=-\frac{804798,7235}{16}=-50299,92$

j. Menentukan F ketidakcocokan

FTc $=\frac{\text { RKtc }}{\text { RKkk }}=-\frac{50299,92}{36600,45}=-1,37$ 
Karena nilai $\mathrm{F}_{\text {hitung }}=-1,37$ sedangkan $\mathrm{F}_{\text {tabel }}$ untuk taraf nyata $\alpha=5 \%$ dari derajat kebebasan (dk:db), dk $=\mathrm{k}-2=18-2=16$; $\mathrm{db}=\mathrm{n}-\mathrm{k}=40-18=22$, maka $\mathrm{F}_{\text {tabel }}(16: 22)=2,13$.

Kesimpulan: karena $F_{\text {hitung }}<F_{\text {tabel }}$ yaitu $-0,58<2,13$ maka metode regresi tersebut berpola linier.

\section{Uji Hipotesis}

Dalam penelitian ini hipotesis akan diuji melalui dua metode statistik berupa uji korelasi dan uji regresi. Adapun data yang akan diuji terdiri dari data Persistensi diri (X) dan Prestasi Belajar Operasi Hitung Pada Bentuk Aljabar (Y).

\section{Uji Regresi Sederhana}

\section{Persamaan Regresi Linier Sederhana}

Dari perhitungan maka diperoleh persamaan regresi linier dari data persistensi diri siswa dan prestasi belajar operasi hitung pada bentuk aljabar sebagai berikut:

$\widehat{\mathrm{Y}}=\mathrm{a}+\mathrm{bX}$

$\widehat{Y}=70,78+0,583 X$

a. Uji Keberartian (Signifikansi) Koefisien Regresi

Menghitung Jumlah Kuadrat Regresi (JKa) dengan rumus:

$$
(\mathrm{JKa})=\frac{\left(\sum \mathrm{Y}\right)^{2}}{\mathrm{n}}=\frac{(2999)^{2}}{40}=\frac{8994001}{40}=224850,025
$$

Menentukan jumlah kuadrat regresi a terhadap b (Jkba)

$$
\mathrm{JKb} / \mathrm{a}=\mathrm{b}\left\{\sum \mathrm{XY}-\frac{\sum \mathrm{x} \sum \mathrm{y}}{\mathrm{n}}\right\}=0,582 \quad\left\{213.715-\frac{2793 \times 2999}{40}\right\}=0,582 \mathrm{x}
$$

$(213.715-209405,175)=0,582 \times 4309,825=2499,69$

Menentukan jumlah residu $(\mathrm{JKr})$

$\mathrm{JKr}=\sum \mathrm{Y}^{2}-\mathrm{Jkb} / \mathrm{a}-\mathrm{Jka}=227761-2499,69-224850,025$

$=411,285$

Menghitung Rata-rata Jumlah Kuadrat Regresi (RJKa)dengan rumus: RJKa = $\mathrm{JKa}=224850,025$

Menghitung Rata-rata Jumlah Kuadrat Regresi (RJKb/a)

$\mathrm{RJKb} / \mathrm{a}=\mathrm{JKb} / \mathrm{a}=2499,69$

Menghitung Rata - rata Jumlah Kuadrat Residu (RJKr) 
$\mathrm{RJKr}=\frac{\mathrm{JKr}}{\mathrm{n}-2}=\frac{411,285}{40-2}=10,82$

Menguji Signifikansi dengan rumus $F_{\text {hitung: }}$ :

$$
F_{\text {hitung }}=\frac{\mathrm{RJKb} / \mathrm{a}}{\mathrm{RJKr}}=\frac{2499,69}{10,82}=231,02
$$

Pengambilan keputusan atau kriteria uji signifikan:

Mencari nilai $\mathrm{F}_{\text {tabel }}$ menggunakan Tabel $\mathrm{F}$ dengan rumus:

Taraf signifikansinya $\alpha=0,05$

$$
\begin{gathered}
\mathrm{F}_{\text {tabel }}=\mathrm{F}_{(1-\alpha)}(\operatorname{dbreg}(\mathrm{b} \mid \mathrm{a}),(\text { dbres }) \\
\mathrm{F}_{\text {tabel }}=\mathrm{F}_{(1-0,05)}\left(\mathrm{db} \mathrm{k-2,db} \mathrm{n-k)} \mathrm{F}_{\text {tabel }}=\mathrm{F}_{(0,95)}(16,22)\right.
\end{gathered}
$$

Cara mencari $\mathrm{F}_{\text {tabel }}: \mathrm{db}=18$, sebagai angka pembilang

$$
\mathrm{db}=22 \text {, sebagai angka penyebut }
$$

$$
\mathrm{F}_{\text {tabel }}=2,35
$$

Membuat kesimpulan: Karena $F_{\text {hitung }}$ lebih besar $F_{\text {tabelyaitu }} 231,02 \geq 2,35$, maka tolak $\mathrm{H}_{\mathrm{o}}$ dan terima $\mathrm{H}_{\mathrm{a}}$. dengan demikian terdapat pengaruh signifikan antara persistensi diri terhadap prestasi belajar operasi hitung pada bentuk aljabar.

\section{Koefisien Korelasi}

Dari perhitungan tabel 4.6 di atas diperoleh $\sum \mathrm{Y}=2999, \sum \mathrm{X}=2793, \sum \mathrm{XY}$ $=213.715, \sum X^{2}=202.419, \sum Y^{2}=227.761, n=40$. Untuk menghitung nilai koefisien korelasi menggunakan rumus korelasi product moment, yaitu:

$$
\begin{aligned}
r_{x y} & =\frac{N \sum x y-\left(\sum x\right)\left(\sum y\right)}{\sqrt{N \sum x^{2}-\left(( \sum X ) ^ { 2 } ( N \sum y ^ { 2 } ) \left(\left(\sum Y\right)^{2}\right.\right.}} \\
& =\frac{8548600-8376207}{\sqrt{295911 X 116439}}=\frac{172393}{\sqrt{34455580929}}=0,9
\end{aligned}
$$

Dari hasil perhitungan analisis korelasi pearson product moment diperoleh harga koefisien $r=0,9$. Artinya bahwa terdapat pengaruh yang signifikan antara persistensi diri siswa $(\mathrm{X})$ terhadap prestasi belajar operasi hitung pada bentuk aljabar (Y). Sehingga prestasi belajar operasi hitung pada bentuk aljabar seorang siswa bisa dipengaruhi oleh persistensi diri siswa itu sendiri. 


\section{Koefisien Determinasi}

Untuk menghitung seberapa besar kontribusi persistensi diri siswa terhadap prestasi belajar operasi hitung pada bentuk aljabar dapat dinyatakan dengan koefisien determinasi yang dapat dihitung dengan rumus:

$\mathrm{KD}=\mathrm{r}^{2} \times 100 \%=(0,9)^{2} \times 100 \%=0,81 \times 100 \%=81 \%$

Dari perhitungan di atas nilai $\mathrm{KD}=81 \%$ ini menunjukkan pada penelitian ini terbukti bahwa persistensi diri siswa mempunyai pengaruh cukup tinggi terhadap prestasi belajar operasi hitung pada bentuk aljabar. Prestasi belajar matematika dipengaruhi oleh faktor persistensi diri siswa sebesar $81 \%$ dan peningkatan prestasi belajar operasi hitung pada bentuk aljabar 19\% dipengaruhi oleh faktor positif lainnya.

\section{Uji Signifikansi koefisien Korelasi}

Uji $\mathrm{t}$ digunakan untuk mengetahui hubungan persistensi diri siswa terhadap prestasi belajar operasi hitung pada bentuk aljabar, yaitu:

Kriteria pengujian :

$t_{\text {hitung }}>t_{\text {tabel }}$, maka signifikan

$\mathrm{t}_{\text {hitung }}<\mathrm{t}_{\text {tabel }}$, maka tidak signifikan.

$t_{\text {hitung }}=\frac{r \sqrt{n-2}}{\sqrt{1-r^{2}}}=\frac{0,9 \sqrt{40-2}}{\sqrt{1-0,9^{2}}}=\frac{0,9 \sqrt{38}}{\sqrt{1-0,81}}=\frac{5,547}{0,43}=12,9$

Nilai $\mathrm{t}_{\text {tabel }}$ dengan taraf signifikan $\alpha=0,05 ; \mathrm{db}=\mathrm{n}-2=40-2=38$. Maka diperoleh nilai $\mathrm{t}_{\text {tabel }}=1,6905$

Karena $t_{\text {hitung }}>t_{\text {tabel }}$ atau 12,9 $>1,6905$ maka signifikan artinya hubungan antara persistensi diri siswa dan prestasi belajar operasi hitung pada bentuk aljabar signifikan.

\section{SIMPULAN}

Pada dasarnya persistensi diri siswa SMP Al-Qalam kelas VIII cukup memuaskan dan membanggakan. Hal ini menunjukan bahwa persistensi diri siswa terhadap pelajaran matematika masih terbilang cukup baik dapat dilihat dari hasil penelitiannya,oleh karena itu hal ini bisa menjadi modal yang cemerlang dan berharga bagi pendidik khususnya untuk mempermudah mengajarkan matematika kepada anak didiknya sehingga tujuan pendidikan matematika di SMP AL-Qalam bisa tercapai dengan baik dan optimal serta maksimal. Adapun prestasi belajar operasi hitung pada bentuk aljabar di SMP AL-Qalam kelas VIII cukup 
membanggakan dapat dilihat dari hasil penelitian. Hal ini menunjukkan bahwa prestasi belajar matematika cukup baik, namun masih harus ditingkatkan kembali.. Sejalan dengan keadaan persistensi diri siswa yang baik seperti yang telah diuraikan di atas ternyata prestasi belajarnya pun menjadi cukup baik.Itu berarti ada suatu ketertarikan antara persistensi diri siswa dengan prestasi belajar operasi hitung pada bentuk aljabar.

Sehingga dalam penelitian ini terbukti bahwa adanya pengaruh positif yang signifikan persistensi diri terhadap prestasi belajar operasi hitung pada bentuk aljabar.

\section{SARAN}

Berdasarkan temuan penelitian di atas maka peneliti menyarankan kepada para guru umumnya dan guru matematika khususnya:

1. Karena guru memiliki peran sentral dalam peningkatan prestasi belajar siswa, maka guru harus senantiasa memotivasi untuk meningkatkan persistensi diri siswa.

2. Dengan meningkatkan persistensi diri, maka akan memiliki dampak langsung terhadap prestasi belajar.

3. Orang tua sebagai guru di rumah memiliki peranan dalam rangka peningkatan persistensi diri siswa. Orang tua harus dijadikan alat untuk membantu guru dalam meningkatkan persistensi diri dalam siswa.

\section{UCAPAN TERIMA KASIH}

Terimakasih kepada kepala sekolah SMP Al-Qalam yaitu Mahidin, S.Pd.I yang telah memberikan izin untuk melakukan penelitian ini. Dan ucapan terimakasih saya sampaikan juga kepada penerbit jurnal RDJE yang dapat menerbitkan artikel penelitian ini.

\section{DAFTAR PUSTAKA}

Bahri Syaiful dan Zain Aswan. 2006. Strategi Belajar Mengajar. Jakarta: PT. Rineka Cipta.

Dimiyati, dan Modjiono. 2006. “ Belajar dan Pembelajaran”. Jakarta : Rineka Cipta. 
Research and Development Journal Of Education

Vol. 5 No. 1 Oktober 2018

ISSN 2406-9744

Peterson, C., \& Seligman, M. E. P. (2004). Character strengths and virtues: A handbook and classification. Washington, DC: American Psychological Association

Sudjana, Nana. 2004. Penilaian Hasil Proses Belajar Mengajar. Bandung: Remaja Rosdakarya. 